\title{
Comparison of the Agricultural Use of Products from Organic Waste Processing with Conventional Mineral Fertilizer: Potential Effects on Mineral Nitrogen Leaching and Soil Quality
}

\author{
Jakub Elb1 1,2,*®i), Jana Šimečková ${ }^{3}$, Petr Škarpa ${ }^{3}$, Antonín Kintl ${ }^{2}$, Martin Brtnický ${ }^{3,4}$ and \\ Magdalena Daria Vaverková 5,6 (iD) \\ 1 Department of Agrosystems and Bioclimatology, Faculty of AgriSciences, Mendel University in Brno, \\ Zemědělská 1, 61300 Brno, Czech Republic \\ 2 Agricultural Research, Ltd., Zahradní 1, 66441 Troubsko, Czech Republic; kintl@vupt.cz \\ 3 Department of Agrochemistry, Soil Science, Microbiology and Plant Nutrition, Faculty of AgriSciences, \\ Mendel University in Brno, Zemědělská 1, 61300 Brno, Czech Republic; \\ jana.simeckova.uapmv@mendelu.cz (J.Š.); petr.skarpa@mendelu.cz (P.Š.); \\ martin.brtnicky@mendelu.cz (M.B.) \\ 4 Institute of Chemistry and Technology of Environmental Protection, Brno University of Technology, Faculty \\ of Chemistry, Purkyňova 118, 62100 Brno, Czech Republic \\ 5 Department of Applied and Landscape Ecology, Mendel University in Brno, Faculty of AgriSciences, \\ Zemědělská 1, 61300 Brno, Czech Republic; magda.vaverkova@uake.cz \\ 6 Institute of Civil Engineering, Warsaw University of Life Sciences-SGGW, Nowoursynowska 159, \\ 02-776 Warsaw, Poland \\ * Correspondence: jakub.elbl@mendelu.cz; Tel.: +420-725-295-999
}

Received: 21 January 2020; Accepted: 29 January 2020; Published: 4 February 2020

\begin{abstract}
Currently, there is an increasing emphasis on the use of renewable sources. The Czech Republic is no exception. There has been an increase in the number of biogas plants and composting plants. The main purpose of these facilities is to process organic wastes of various origins in order to utilize the waste, both for energy production and as soil fertility enhancers. Last but not least, the biogas station produces digestate, which could be further utilized. The present work deals with the assessment of the effect of digestate (doses of 220; 150 and $80 \mathrm{~kg} \mathrm{~N}^{-1}$ ), mineral fertilizer (150 kg N $\left.\mathrm{ha}^{-1}\right)$, and compost application (150 $\mathrm{kg} \mathrm{N} \mathrm{ha}^{-1}$ ) on selected indicators of soil environment: (a) soil microbial activity (basal and substrate-induced respiration); (b) plant nutrient content ( $\mathrm{P}, \mathrm{K}, \mathrm{Ca}, \mathrm{Mg}$ ); (c) leaching mineral $\mathrm{N}$ from the soil; and (d) production of plant biomass of model plant Lactuca sativa L. Furthermore, the work aims to assess the individual doses of digestate and to determine the optimal one. The above effects were studied within a pot experiment for 63 days in controlled conditions. There were significant differences in $\mathrm{N}_{\min }$ leaching, which was significantly the highest in the variant with the application of a mineral fertilizer and lowest in variants with the application of digestate (variant 150 and $80 \mathrm{~kg} \mathrm{~N} \mathrm{ha}^{-1}$ ) and compost (150 kg N ha ${ }^{-1}$ ). In terms of soil microbial activity, a significant effect of digestate application $\left(150 \mathrm{~kg} \mathrm{~N} \mathrm{ha}^{-1}\right)$ on basal respiration versus the mineral fertilizer application was found (difference $>20 \%$ ). This dose of digestate also had the highest positive effect on substrate-induced respiration, proven against all other variants, except for the digestate application at $220 \mathrm{~kg} \mathrm{~N} \mathrm{ha}^{-1}$. Particularly, as compared with the mere application of mineral fertilizer, the application of digestate dose at $150 \mathrm{~kg} \mathrm{~N} \mathrm{ha}^{-1}$ had the best positive effect on plant biomass production $(+20 \%)$. On the other hand, compost application most positively affected the increase in available contents of nutrients and thus long-term soil fertility. Therefore, the dose of $150 \mathrm{~kg} \mathrm{~N} \mathrm{ha}{ }^{-1}$ digestate may represent an interesting alternative to increase actual soil fertility and thus to partially replace conventional mineral nutrition.
\end{abstract}


Keywords: digestate; compost; waste; fertility; mineral nitrogen; leaching

\section{Introduction}

Until about four decades ago, crop yields in agricultural systems depended on internal resources, recycling of organic matter, built-in biological control mechanisms, and rainfall patterns. Agricultural yields were modest, yet stable. Production was safeguarded by growing more than one crop or variety in space and time in the field as insurance against pest outbreaks or severe weather conditions. Inputs of nitrogen were gained by rotating major field crops with legumes [1]. Currently, crop yield depends on the application of minerals fertilizers, the main reason being declining natural fertility of soils caused by decreasing soil organic matter (SOM) content.

The SOM plays a central role in maintaining or improving soil fertility, providing nutrients and maintaining favorable physical and biological properties of soil [2]. The SOM-balance in agricultural soil depends on natural inputs and outputs, and on the application of biomass such as manure and waste-derived products, i.e. sewage sludge, compost and digestate [3-5]. SOM and texture are important factors affecting the rate of carbon and nitrogen mineralization in soils under conditions of constant temperature and water content and hence soil fertility-availability of nutrients in the soil rhizosphere [6]. The SOM is immense in supporting biological populations in the soil. The SOM has a huge effect on the number and kinds of organisms that are present in the soil, being indispensable for the achievement of high quality and healthy soil—in other words, sustainable soil [4,7-9].

There are several possibilities to improve the soil content of SOM and thus reduce the risk of soil degradation and increase the level of soil fertility. One is the application of OM originating as a by-product (waste) such as digestate and organic fertilizer, such as compost (Regulation EU 2019/1009). Caracciolo et al. [10] state that anaerobic digestion is an efficient biological method to use livestock and agro-industrial wastes in the production of energy and that it transforms organic wastes into two products: the source of renewable energy (biogas) and the digested material as a potential fertilizer (digestate). According to Diaz et al. [11], compost is the main product of the composting process, which may be defined as a stabilized and sanitized product of composting. Compost is classified in the group of so-called organic waste products (OWP), which are being increasingly applied to soils because they facilitate recycling of nutrients and improve soil fertility. OWP represent an interesting, and possible indispensable source of organic matter for agricultural soils [1,2]. Above all, the chemical compounds in compost are interesting for soil microorganisms and plants [11,12]. In addition, compost is also a source of essential plant nutrients, adds SOM, and improves soil quality and structure [13]. The most important available compost substances include organic carbon, two forms of nitrogen (organic and inorganic), and phosphorus [14]. More than $85-90 \%$ of the total nitrogen content in compost is organic, while the remaining $10-15 \%$ is inorganic and immediately available to plants [15]. Furthermore, digestate, a semi-solid residue obtained after biomass extraction from anaerobic digestion, is considered a vital source of organic matter and nutrients, namely nitrogen [16]. Digestate is currently gaining great importance as it contains a certain amount of plant nutrients and organic matter and can be used as organic fertilizer or soil conditioner [17]. On the other hand, the long-term effect of digestate application remains questionable $[16,17]$.

Soil fertility can be increased for a short time by the application of mineral fertilizers (MF). Mineral nitrogen represents one of the most important nutrients, both for soil organisms and for plants reaching through their roots into the soil environment. On the other hand, excessive $\mathrm{N}$ application accelerates its loss through ammonia volatilization, denitrification, surface runoff, and leaching of mineral forms $[18,19]$.

The main aims of this study are as follows: (i) to determine an optimal dose of digestate in relation to soil fertility and leaching of mineral nitrogen, (ii) to compare digestate and compost with conventional mineral fertilizers in terms of their influence on soil microbial activity, on the content of 
soil nutrients available to plants, and on plant biomass production. The above aims were monitored using a pot experiment established under controlled conditions in a growth box.

\section{Materials and Methods}

\subsection{Laboratory Experiment}

The experiment was a laboratory assay and pots for the incubation experiment were prepared as follows (Table 1): $800 \mathrm{~g}$ of arable soil with or without the addition of digestate (DG), compost (CP), and mineral (nitrogen) fertilizer (MF) was placed in each plastic pot (Figure 1 and Appendix A). CP samples were purchased in Central Composting Plant Brno "CKB a.s" company. Soil sampling was carried out according to CSN ISO $10381-6$ and CP sampling complied with CSN EN 46 5735. DG sampling was realized according to CSN EN 14 899. The chemical and physical properties of used soils and soil supplements are presented below (Tables 2-4).

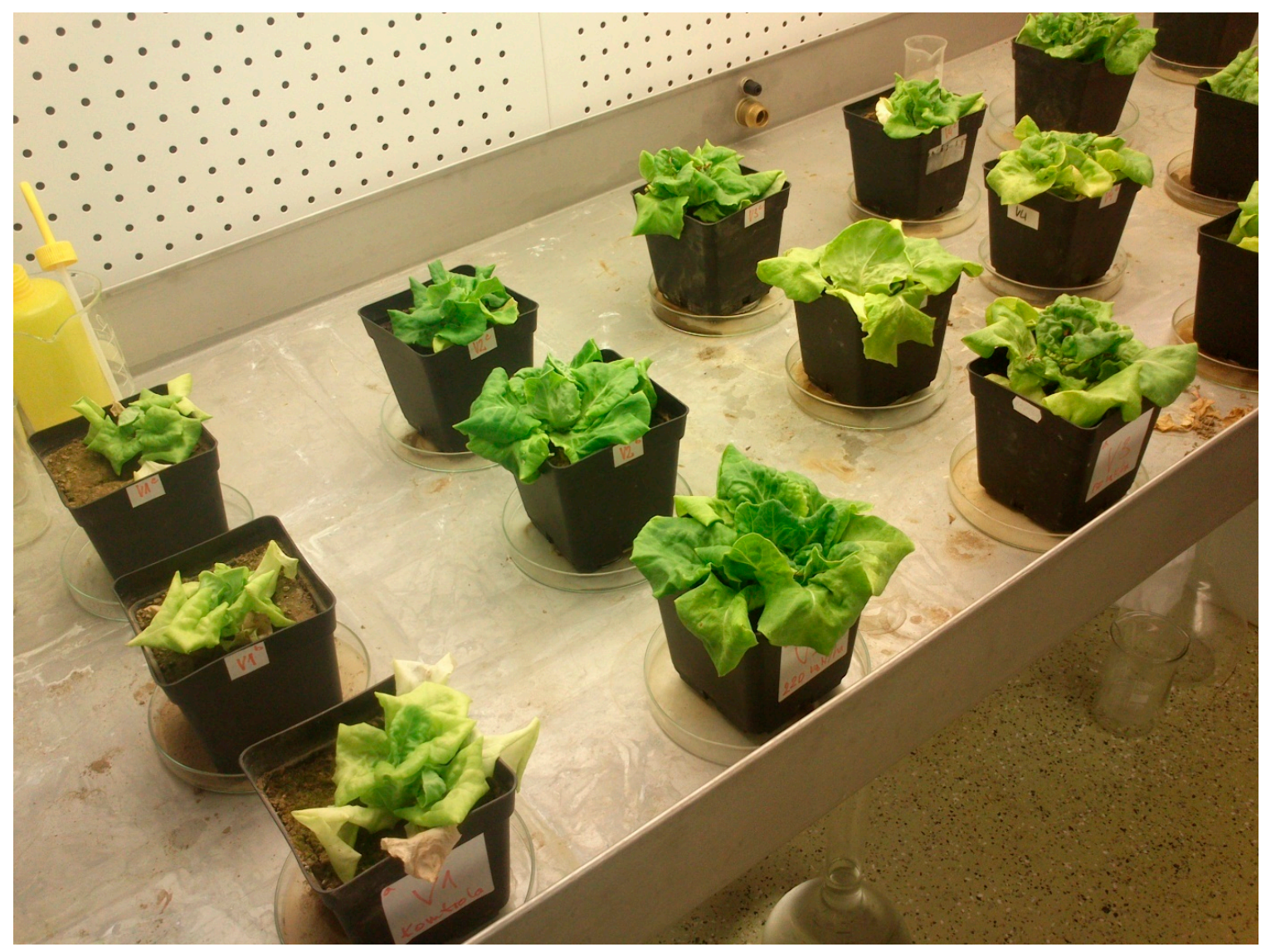

Figure 1. Placement of experimental containers in the growth box.

The experiment was conducted in a cultivation box (phytotron) where the indicator plant Lactuca sativa L. (lettuce) was cultivated for 63 days under the following conditions: temperature $22{ }^{\circ} \mathrm{C}$, day length $12 \mathrm{~h}$ and light intensity $300 \mu \mathrm{mol} \mathrm{m} \mathrm{m}^{-2} \mathrm{~s}^{-1}$. The cultivation box (phytotron) environment was monitored by a computer system (temperature, humidity, and light sensors). Temperature was controlled using the air-conditioning system. The required environment humidity was achieved by using (distilled) water sprayers. At the beginning of the experiment, soil moisture in all experimental containers was induced at 70\% of water holding capacity (WHC). Irrigation water was distilled. The need for watering was determined by weighing the experimental containers. First, container weight was determined when the soil reached the required WHC value. If a lower container weight was recorded, the weight drop was compensated for by irrigation to reach $70 \%$ of WHC. This procedure 
continued to be used until the experimental plants grew, which were then irrigated with a constant dose of $100 \mathrm{~mL} \mathrm{1x}$ in two days. In the given conditions, this dose was sufficient to reach optimal soil moisture without negative effects on the development of plants and water loss from the experimental containers. Lettuce was chosen as an indicator plant according to D'antuono and Neri [20], where the authors confirmed the positive correlation between the production of lettuce biomass and the availability of soil $\mathrm{N}$ due to the application of different fertilizers.

There were six experimental variants (Table 1) prepared at three repetitions within a completely randomized design (18 containers were used). The control variant was not fertilized. The other variants were fertilized with DG, CP, and MF. Doses of the fertilizers were set based on N content in order to prepare comparable variants, i.e. a particular substance was dosed in order to prepare 3 variants with $150 \mathrm{~kg} \mathrm{~N} \mathrm{ha}^{-1}$ (CP, NPK and DG 150), 1 variant with $220 \mathrm{~kg} \mathrm{~N} \mathrm{ha}^{-1}$ (DG 220), and 1 variant with $80 \mathrm{~kg}$ $\mathrm{N} \mathrm{ha}^{-1}$ (DG 80). Thus, the $\mathrm{N}$ doses used in the experiment to mark the variants were equivalents of fertilizer doses in $\mathrm{kg} \mathrm{ha}^{-1}$.

Table 1. Overview of the laboratory experiment.

\begin{tabular}{|c|c|c|c|c|c|c|c|}
\hline \multirow{2}{*}{ Treatment } & \multirow{2}{*}{ Abb. } & \multirow{2}{*}{$\begin{array}{l}\text { Dose of } N \\
\left(\operatorname{kg~N~ha~}^{-1}\right)\end{array}$} & \multirow{2}{*}{$\begin{array}{l}\text { Dose of Fertilizer } \\
\quad\left(\mathrm{kg} \mathrm{ha}^{-1}\right)\end{array}$} & \multicolumn{4}{|c|}{ Nutrient Input (kg ha-1) } \\
\hline & & & & $\mathbf{P}$ & $\mathbf{K}$ & $\mathrm{Ca}$ & $\mathrm{Mg}$ \\
\hline Control & - & 0 & - & 0 & 0 & 0 & 0 \\
\hline Digestate & DG 80 & 80 & 25,806 & 21 & 126 & 49 & 21 \\
\hline Digestate & DG 150 & 150 & 48,387 & 39 & 237 & 92 & 39 \\
\hline Digestate & DG 220 & 220 & 70,968 & 57 & 348 & 135 & 57 \\
\hline Mineral fertilizer & NPK & 150 & 1500 & 150 & 150 & - & - \\
\hline Compost & $\mathrm{CP}$ & 150 & 9416 & 5 & 60 & 106 & 12 \\
\hline
\end{tabular}

Comment: Description of variants informs on the dosing of fertilizers, which was carried out based on the $\mathrm{N}$ content. The amount of nutrients $(\mathrm{P}, \mathrm{K}, \mathrm{Ca}, \mathrm{Mg})$ applied to soil in the respective variants was calculated based on the chemical composition of DG and CP (see Table 3).

\subsection{Soil Supplements}

DG was produced at a biogas plant in "Nové město na Moravě" (Czech Republic). DG used for the experiment can be defined as a fermentation residue from the anaerobic digestion of feedstock during biogas production in the plant. Samples of DG were collected at the end of the fermentation process, i.e. before storage in silos. The remainder of the fermentation was not treated before the application in any way (e.g. by separation, etc.). The feedstock material consisted of cow manure, grass silage, and maize silage. The CP (organic waste compost) "Black Dragon" was used as a second organic fertilizer. This type of CP meets all parameters (humidity, phytotoxicity, and nutrient contents) prescribed by CSN EN 46 5735. The chemical composition of DG and CP is presented in Table 2. NF was applied as a solid fertilizer GSH-NPK containing $\mathrm{N}, \mathrm{P}_{2} \mathrm{O}_{5}, \mathrm{~K}$, and $\mathrm{SO}_{3}$ in the ratio 10:10:10:13). The CP and MF fertilizers used are registered for agricultural use in the Czech Republic (pursuant to Fertilizers Act No.: 156/1998).

Table 2. Chemical characteristics of digestate and compost.

\begin{tabular}{cccccc}
\hline \multirow{2}{*}{ Fertilizers } & \multicolumn{3}{c}{ Parameter $\left(\mathbf{m g ~ k g}^{-\mathbf{1}}\right)$} & \multirow{2}{*}{$\mathbf{p ~ C a C l}_{\mathbf{2}}$} & \multirow{2}{*}{$\mathrm{C}: \mathbf{N}$} \\
\cline { 2 - 5 } & Dry matter & $\mathrm{C}_{\text {tot }}$ & $\mathbf{N}_{\text {total }}$ & & \\
\hline Digestate & 92 & 4 & 3.1 & 8.17 & 1.29 \\
\cline { 2 - 5 } Compost & 550 & 182 & 13.1 & 7.41 & 13.9 \\
\hline
\end{tabular}

\subsection{Basal and Substrate-Induced Respiration}

Substrate-induced respiration (SIR) was determined according to Šimek et al. [21]: (a) Basal respiration (BAS) was set by $\mathrm{CO}_{2}$ production measurement from soils incubated in serum bottles for 
$24 \mathrm{~h}$. A sample of field moist soil $(15 \mathrm{~g})$ was placed into three $120-\mathrm{mL}$ serum bottles sealed with butyl rubber stoppers and incubated at $25^{\circ} \mathrm{C}$. After 3 and $24 \mathrm{~h}$, a $0.5 \mathrm{~mL}$ sample of internal atmosphere was analyzed in each bottle by gas chromatography (Agilent Technologies 7890A GC System equipped with a thermal conductivity detector). Respiration is based on $\mathrm{CO}_{2}$ increase within $21 \mathrm{~h}$ incubation (24-3 h). (b) SIR was measured on the basis of $\mathrm{CO}_{2}$ production using 4-h incubation of soil in serum bottles and addition of glucose. Three replicates of field-moist soil $(5 \mathrm{~g})$ were enriched with $2 \mathrm{~cm}^{3}$ of glucose solution ( $4 \mathrm{mg} \mathrm{C} \mathrm{g}^{-1}$ of dry soil), placed in serum bottles sealed with butyl rubber stoppers, and incubated at $25^{\circ} \mathrm{C}$. The analysis of internal atmosphere $\left(0.5 \mathrm{~cm}^{3}\right)$ was carried out two times (after 2 and $4 \mathrm{~h}$ ) by gas chromatography (Agilent Technologies 7890A GC System equipped with a thermal conductivity detector). The resulting values of SIR were calculated on the basis of $\mathrm{CO}_{2}$ production after $4 \mathrm{~h}$ of incubation, as per Šimek et al. [21]. The results are expressed in micro gram of $\mathrm{CO}_{2}$ per gram of soil and one hour.

\subsection{Analysis of Arable Soil Chemical Properties}

Available nutrients- $\mathrm{P}, \mathrm{K}, \mathrm{Ca}$, and $\mathrm{Mg}$ - in soil samples were extracted by Mehlich III according to Mehlich [22]. Subsequently, the content of these nutrients in the extract was measured in accordance with the standard issued by the Czech Central Institute for Supervising and Testing in Agriculture [23], which was used, for example, by Maňásek et al. [24]: atomic absorption spectrometry (AAS) was used to determine the content of available potassium $(\mathrm{K})$, magnesium $(\mathrm{Mg})$, and calcium $(\mathrm{Ca})$; while available phosphorus $(\mathrm{P})$ was determined colourimetrically in the extract. $\mathrm{PH}$ value was detected using the ion-selective electrode method after extraction in $0.01 \mathrm{M} \mathrm{CaCl}_{2}$. The soil samples were analysed before and after the experiment. $\mathrm{C}_{\text {tot }}$ and $\mathrm{N}_{\text {tot }}$ in the samples were measured using the high-temperature $\left(1000^{\circ} \mathrm{C}\right)$ dry combustion method according to Uzoma et al. [25] with an automatic analyser LECO CNS 2000.

The basic soil properties of topsoil (before the establishment of the experiment) are summarized in Tables 3 and 4. The data show that soil adsorption complex had a sufficient supply of nutrients and soil reaction was acidic. Based on these data, the authors conclude that the content of available nutrients in the topsoil did not directly affect the main objectives of the experiment. Topsoil particle sizes: clay $(<2 \mu \mathrm{m}$, wt $\%)$ 11.69; silt (50-2 $\mu \mathrm{m}$, wt \%) 34.87; and sand (2000-50 $\mu \mathrm{m}$, wt $\%)$ 53.44. Soil structure was sandy loam.

Table 3. Agrochemical properties-plant-available nutrient content of soil samples and fertilizers used for the establishment of the experiment (luvisol modal, sandy loam soil).

\begin{tabular}{cccccc}
\hline \multirow{2}{*}{ Sample } & \multicolumn{4}{c}{ Parameter $\left(\mathbf{m g ~ k g}^{\mathbf{- 1}}\right)$} & \multirow{2}{*}{ K:Mg } \\
\cline { 2 - 5 } & $\mathbf{P}$ & $\mathbf{K}$ & $\mathbf{C a}$ & $\mathbf{M g}$ & \\
\hline \multirow{2}{*}{ Topsoil } & 39 & 278 & 735.00 & 176 & 1.57 \\
& low & good & low & good & suitable \\
Digestate & 800 & 4900 & 1900 & 800 & 6.1 \\
Compost & 565 & 6422 & 11,235 & 1255 & 5.1 \\
\hline
\end{tabular}

Table 4. Agrochemical properties—soil reaction and salinity of soil samples used for the establishment of the experiment (luvisol modal, sandy loam soil).

\begin{tabular}{ccccc}
\hline Soil Sample & $\mathbf{p H}\left(\mathrm{CaCl}_{\mathbf{2}}\right)$ & $\mathbf{p H}\left(\mathbf{H}_{\mathbf{2}} \mathbf{O}\right)$ & $\mathrm{EC}\left(\mathrm{dS} \mathrm{cm} \mathbf{c m}^{-\mathbf{1}}\right)$ & $\mathrm{TDS}\left(\mathrm{mg} \mathrm{L}^{-\mathbf{1}}\right)$ \\
\hline Topsoil & $\begin{array}{c}5.77 \\
\text { strongly acidic }\end{array}$ & $\begin{array}{c}6.4 \\
\text { weakly acidic }\end{array}$ & 0.11 & 72.3 \\
\hline
\end{tabular}

\subsection{Leaching of Mineral Nitrogen}

The method to measure leaching of mineral nitrogen was carried out according to Novosadová et al. [26]. Mineral nitrogen ( $\mathrm{N}_{\mathrm{min}}$; consisting of ammonium and nitrate nitrogen) that leached out of 
the experimental container was captured by ion exchange resin grains. The grains placed into special plastic (PVC) discs were fixed under the containers. Each disc was made of a plastic ring of $75 \mathrm{~mm}$ width and $5 \mathrm{~mm}$ thickness. A nylon mesh was glued to both sides of each disc. After the experiment, the discs were removed from the Petri dishes (placed under the containers; Appendix A, Figures A1 and A2) and dried at $18{ }^{\circ} \mathrm{C}$ (laboratory temperature) for 7 days. Dry IER was removed from the discs and divided by variant. Extraction of $\mathrm{N}_{\min }$ trapped ions from resins was enabled by $100 \mathrm{~mL}$ of $1.7 \mathrm{M} \mathrm{NaCl}$. Their concentration was assessed by the distillation and titration method according to Muñoz-Huerta et al. [27].

\subsection{Statistical Analysis}

The results were assorted and processed by the programme MS Excel 2013 (Microsoft, Redmond, Washington, USA). Potential differences in microbial activity, content of soil nutrients, and plant biomass production were analyzed by the Statistica 13 (Dell Software, Round Rock, Texas, USA) program. One-way analysis of variance (ANOVA), in combination with the post-hoc Tukey's HSD test (both at a level of $p<0.05$ ), was used to identify the above differences. Furthermore, the dimensionality-reduction method of Principal Component Analysis (PCA) providing dimension reduction in combination with regression analysis (RA) was used to analyze the relationship between the individual parameters and to identify the main factor to explain the measured variance.

\section{Results and Discussion}

\subsection{Basal and Substrate-Induced Respiration}

The measured results of BAS (Figure 2) show the different effects of DG and CP on soil basal respiration in comparison to MF. As compared with the NPK variant, a significantly highest level of BAS $\left(>0.16 \mu \mathrm{g} \mathrm{CO}_{2} \mathrm{~g}^{-1} \mathrm{~h}^{-1}\right)$ was detected in variants where identical doses $\left(150 \mathrm{~kg} \mathrm{~N}^{-1}\right)$ of DG and $\mathrm{CP}$ were applied. On the other hand, there were only insignificant differences between the control and the DG 220, DG 150, DG 80, and CP variants.

Substrate-induced respiration (SIR) was significantly influenced by the fertilizer treatments. The lowest $(p<0.05)$ value of SIR was found in the control variant $\left(3.14 \mu \mathrm{g} \mathrm{CO}_{2} \mathrm{~g}^{-1} \mathrm{~h}^{-1}\right)$. Conversely, the highest value of SIR was detected in the variant with DG $150\left(150 \mathrm{~kg} \mathrm{~N} \mathrm{ha}^{-1}\right)$. As compared with the other variants (except for DG 220), the addition of DG at a dose of $150 \mathrm{~kg}$ N/ha increased SIR significantly. The application of the higher dose of DG $\left(220 \mathrm{~kg} \mathrm{~N} \mathrm{ha}^{-1}\right)$ did not significantly increase SIR in comparison with the lower dose of DG $\left(80 \mathrm{~kg} \mathrm{~N} \mathrm{ha}^{-1}\right)$ and the dose of MF and CP $(150 \mathrm{~kg} \mathrm{~N}$ $\mathrm{ha}^{-1}$ ). Soil respiration was not positively associated with the $\mathrm{N}$ dose. Furthermore, the $\mathrm{CP}$ addition increased SIR (5.4 $\left.\mu \mathrm{g} \mathrm{CO}_{2} \mathrm{~g}^{-1} \mathrm{~h}^{-1}\right)$ compared to the variant with MF $\left(4.7 \mu \mathrm{g} \mathrm{CO}_{2} \mathrm{~g}^{-1} \mathrm{~h}^{-1}\right)$.

In soil microbial ecology, the actual (basal respiration, BAS) and potential microbial respirometric activity (substrate-induced respiration, SIR) are well-established and widely used indicators of microbial activity [28]. In addition, Bloem et al. [29] state that the substrate-induced respiration method is based on the detection of a respiratory response of soil microorganisms to the supply of glucose. Thus, only glucose-responsive and active organisms were measured. SIR was selected as an indicator of microbial activity to react to the addition of C-substances and participate in important soil processes. Thus, it can be concluded that the increasing dose of $\mathrm{N}$ can be negative for soil microbial activity, which is in accordance with Geisseler et al. [30].

The above results (see Figure 2, Table 5) indicate that the effect of $\mathrm{N}$ dose on BAS/SIR was secondary. The composition (ratio of $\mathrm{C}: \mathrm{N}$, content of $\mathrm{N}_{\text {org }}$ and $\mathrm{N}_{\text {tot }}$ ) of fertilizers primarily influenced the development of microbial community in the soil. It is significant if we compare the values with the MF application variant. Geisseler et al. [30] report that soil microorganisms can use a wide range of $\mathrm{N}$ compounds. These include inorganic compounds such as ammonium- $\mathrm{N}$ and nitrate- $\mathrm{N}$, as well as organic molecules such as amino acids and small peptides. We observed that the optimal dose of DG, which had a positive effect on the development of microbial community, was $150 \mathrm{~kg} \mathrm{~N} \mathrm{ha}^{-1}$. Moreover, 
a positive effect of $\mathrm{CP}$ addition on the soil microbial activity was found in comparison with the variant without the addition of fertilizers and the MF variant. These differences were found also in other studies [10-12].

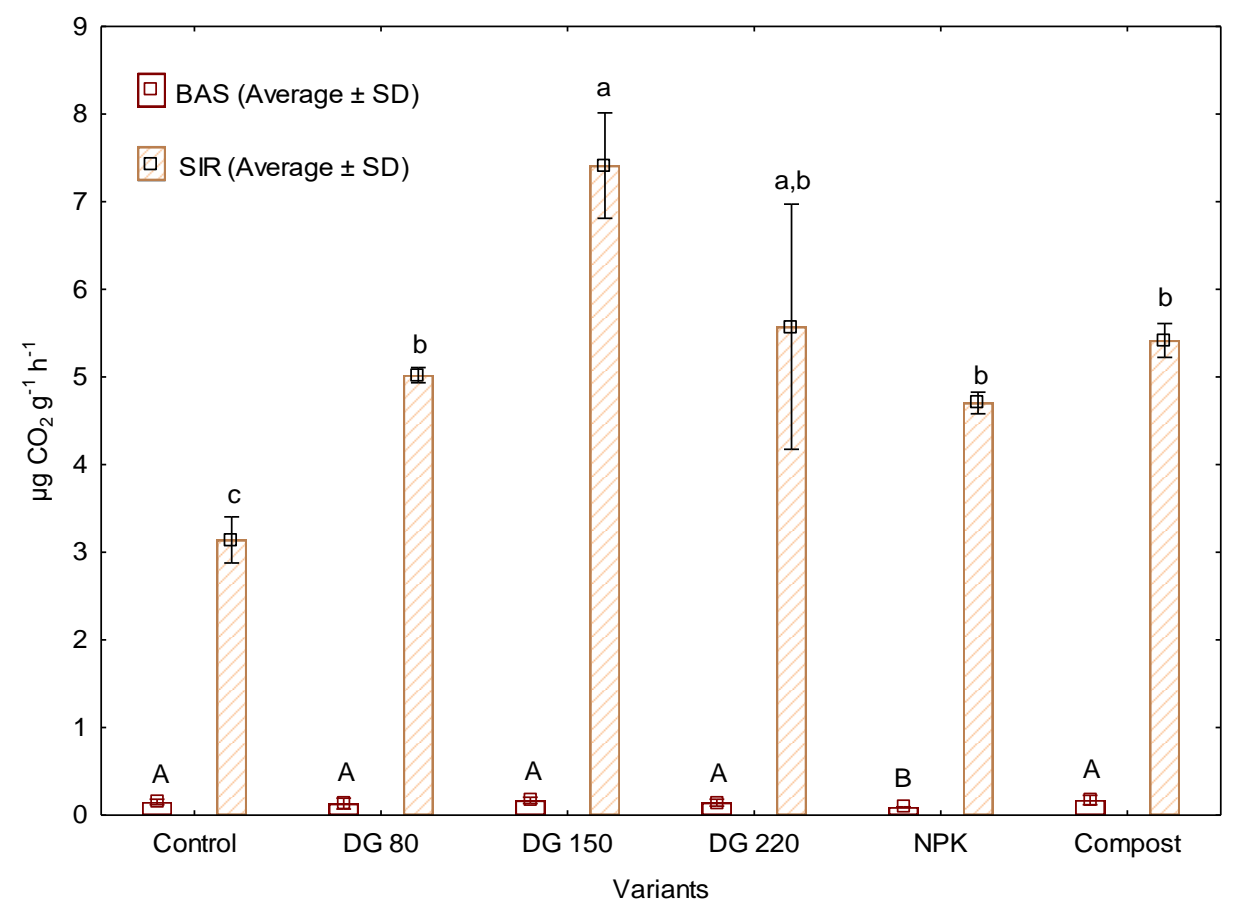

Figure 2. Basal and substrate-induced respiration. Comment: Average BAS and SIR $(n=3 ; \pm \mathrm{SD})$. Different upper case letters represent HSD (honestly significant difference; post-hoc Tukey's test; $p<0.05)$ in the BAS and lower case letters in SIR. DG = digestate, NPK = mineral fertilizer containing $\mathrm{N}, \mathrm{P}, \mathrm{K}$, and $\mathrm{S}$ in the ratio 10:10:10:13.

Table 5. The percentage differences in BAS and SIR.

\begin{tabular}{cccc}
\hline \multirow{2}{*}{ Variant } & \multirow{2}{*}{ Dose of N (kg ha $\left.{ }^{-1}\right)$} & \multicolumn{2}{c}{ Differences } \\
& & BAS & SIR \\
\hline Control & 0 & $100 \%$ & $100 \%$ \\
DG 80 & 80 & $88 \%$ & $160 \%$ \\
DG 150 & 150 & $112 \%$ & $236 \%$ \\
DG 220 & 220 & $95 \%$ & $177 \%$ \\
NPK & 150 & $62 \%$ & $150 \%$ \\
Compost & 150 & $115 \%$ & $172 \%$ \\
\hline
\end{tabular}

Comment: DG = digestate, NPK = mineral fertilizer containing N, P, K and S in the ratio 10:10:10:13.

It is therefore evident that the high $\mathrm{N}$ dose $(220 \mathrm{~kg} \mathrm{~N})$ applied in DG resulted in the decrease of SIR; its value at the level of $80 \mathrm{~kg} \mathrm{~N}$ (DG) is similar, where N is in deficit. High solubility of nitrogen from MF resulted in surplus $\mathrm{N}$ (documented by $\mathrm{N}_{\min }$ leaching-Figure 3) due to which microbial activity was reduced (restricted respiration). Compost (fertilizer with the C:N ratio over 10) did not provide enough mineral $\mathrm{N}$ for the development of microorganisms at a dose of $150 \mathrm{~kg} \mathrm{~N} \mathrm{ha}^{-1}$ and the respiration rate was similar to that recorded at a dose of $80 \mathrm{~kg} \mathrm{~N}$ applied in DG. 


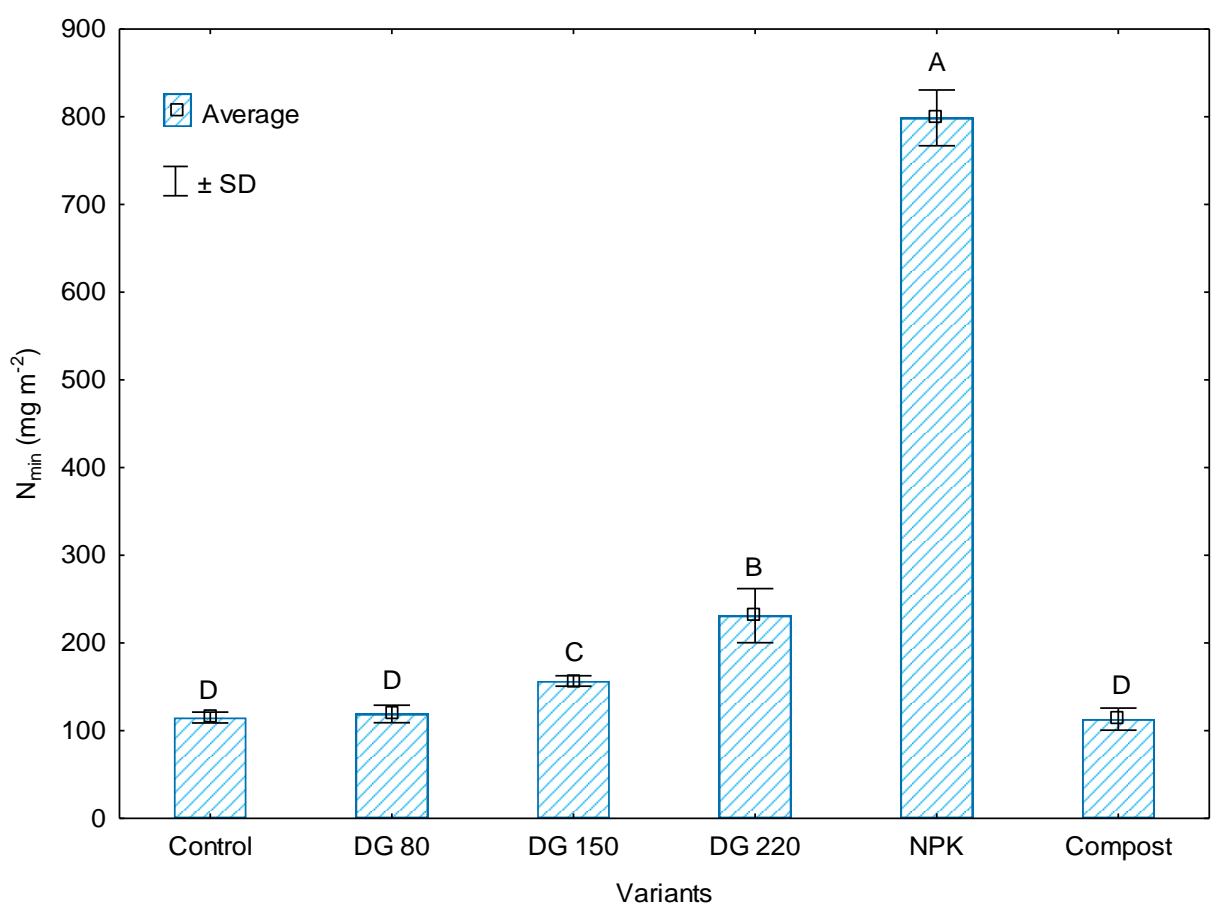

Figure 3. Leaching of mineral nitrogen. Comment: Average $\mathrm{N}_{\min }$ loss from the soil $(n=3 ; \pm \mathrm{SD})$. Different upper case letters represent HSD (honestly significant difference; post-hoc Tukey's test; $p<0.05$ ) in the leaching of $\mathrm{N}_{\min }$. DG = digestate, $\mathrm{NPK}=$ mineral fertilizer containing $\mathrm{N}, \mathrm{P}, \mathrm{K}$, and $\mathrm{S}$ in the ratio 10:10:10:13.

\subsection{Plant Available Nutrient Content in Soil at the End of the Experiment}

The addition of DG, MF, and CP caused significant ( $p<0.05$; ANOVA) changes in the content of available nutrients $(\mathrm{P}, \mathrm{K}, \mathrm{Ca}$, and $\mathrm{Mg})$. The values prove $(p<0.05)$ the effect of addition of particular nutrients and fertilizers on the change in content of plant available nutrients in soil in terms of content increase, compared to the state before the experiment and in terms of values fluctuations between the experimental variants, mainly when comparing the control variant and variants with the addition of $\mathrm{DG}, \mathrm{CP}$, and MF.

Tables 6 and 7 show that the greatest changes were found in the contents of $P, K$, and Ca between the variants where DG, $\mathrm{CP}$, or MF was applied and the initial content of the above nutrients in the soil before the experiment or in the control variant. Firstly, the changes in the contents of P: DG, CP, and NF application significantly increased $\mathrm{P}$ substances in the soil. The significantly highest content of $\mathrm{P}$ plant-available substances in the soil was found in the variant with MF. It was probably caused by the composition of fertilizers, where besides N, P and K were also applied (Table 1). Table 6 shows that the MF addition caused increase in soil $\mathrm{P}$ content by $359 \%$, when compared to the previous state. Another interesting indicator is $\mathrm{P}$ increase even in the control variant, which was probably caused by releasing $\mathrm{P}$ from bonds of the soil substances as a result of regular irrigation, phosphorus desorption caused by the change of the SOM content, and composition and effect of the model plant [31]. The same results were published by [32]. The authors point to the ability of releasing P within pot experiments. The second-highest $\mathrm{P}$ content in the soil (significantly different from the other variants) was detected in the variant with the $\mathrm{CP}$ addition, where compost contained less P substances; however, Diaz et al. [11] and other studies $[33,34]$ claim the substances are present in more readily available forms, when compared to mineral fertilizers or DG.

Data in Table 1 show that the soil where $\mathrm{CP}$ was applied received less $\mathrm{P}$ when compared to DG or MF variants. On the other hand, studies $[11,35,36]$ claim that the nutrient was present in a more readily available form in soil because decomposition of organic matter (from $\mathrm{CP}$ ) resulted in the release 
of organic compounds, often in the form of organic acids. These subsequently enter bonds with Fe and $\mathrm{Ca}$, by which they reduce absorption of water-soluble $\mathrm{P}$. The phenomenon is referred to as the 'humus effect'.

Table 6. Percentage differences in plant available nutrient contents between the initial state and that at the end of the experiment.

\begin{tabular}{lccccc}
\hline \multirow{2}{*}{ Variant } & \multirow{2}{*}{ Dose of N (kg ha $\left.{ }^{-1}\right)$} & \multicolumn{4}{c}{ Differences } \\
\cline { 3 - 6 } & & $\mathbf{P}$ & $\mathbf{K}$ & $\mathbf{C a}$ & $\mathbf{M g}$ \\
\hline Soil—default & 0 & $100 \%$ & $100 \%$ & $100 \%$ & $100 \%$ \\
value & 0 & $+213 \%$ & $-2 \%$ & $+23 \%$ & $+4 \%$ \\
Control & 80 & $+211 \%$ & $+7 \%$ & $+19 \%$ & $+1 \%$ \\
DG 80 & 150 & $+211 \%$ & $+31 \%$ & $+18 \%$ & $+3 \%$ \\
DG 150 & 220 & $+222 \%$ & $+105 \%$ & $+16 \%$ & $+5 \%$ \\
DG 220 & 150 & $+361 \%$ & $+32 \%$ & $+34 \%$ & $-2 \%$ \\
NPK & 150 & $+242 \%$ & $+24 \%$ & $+42 \%$ & $+9 \%$ \\
Compost & & & &
\end{tabular}

Comment: Percentage differences between the control and the other variants. DG = digestate, NPK $=$ mineral fertilizer containing $\mathrm{N}, \mathrm{P}, \mathrm{K}$, and $\mathrm{S}$ in the ratio 10:10:10:13.

Considering the content of $\mathrm{P}$ and $\mathrm{Ca}$ in the DG variants $\left(150 \mathrm{~kg} \mathrm{~N} \mathrm{ha}^{-1} ; 80 \mathrm{~kg} \mathrm{~N} \mathrm{ha}^{-1}\right)$, the data indicated that the addition of DG caused decreased $\mathrm{P}$ and Ca content in comparison with the control (without significance $p<0.05$ ), but this value was higher than the soil content of $\mathrm{P}$ and $\mathrm{Ca}$ used for the establishment of the experiment.

This situation was probably related to the composition of DG, where the ratio of $\mathrm{C}$ and $\mathrm{N}$ content was lower (1.29) than in CP (13.9). DG also contained less solid organic matter, which is the main carrier of $P$ substances $[31,32,36]$ in comparison with CP. Therefore, such mineralization processes could not occur as in the $\mathrm{CP}$ variants. A similar situation was found in Ca content, where a significant increase (compared to all other variants) was due to $\mathrm{CP}$ and MF applications. $\mathrm{CP}$ had the greatest influence on the increase of plant-available $\mathrm{Ca}$, compared to the pre-experiment and the control. The detected increase was by more than $40 \%$. The second highest content of Ca was found in the variant with the addition of MF. Ca concentration was again higher, compared to the other variants; for example, by $34 \%$, as compared with the initial state of the experiment. The high content of available Ca in the variant with the application of MF could also explain the high content of $\mathrm{NH}_{4}$ nitrogen, which can displace the divalent cation from the physical-chemical absorption if its concentration is increased. Its greatest loss was recorded exactly in the variant with MF. A different situation was found in the variants with different DG doses. The Ca content increased only by $20 \%$ (Table 6 ). The increase was not conclusive for the control variant. It was detected in the variant with the highest dose of DG $\left(220 \mathrm{~kg} \mathrm{~N} \mathrm{ha}^{-1}\right)$.

The soil K content was significantly affected by the addition of DG $\left(220 \mathrm{~kg} \mathrm{~N} \mathrm{ha}^{-1}\right)$, when compared to the other variants. This was probably due to the composition of DG (Table 3) and the amount of K in individual doses of DG (Table 1: input of $\mathrm{K}$ from $348 \mathrm{~kg} \mathrm{ha}^{-1}$ to $126 \mathrm{~kg} \mathrm{ha}^{-1}$ ), affecting the amount of $\mathrm{K}$ entering the soil (Table 3). It is also necessary to note that the increase in plant-available soil $\mathrm{K}$ content was also detected in other variants, but the differences were not statistically significant, as compared with the control or pre-experiment soil condition. Contrarily, a decrease in K content was found in the control soil variant (by $2 \%$ less when compared to the pre-experiment soil condition). However, the difference was not significant. 
Table 7. Agrochemical characteristics-plant-available nutrient content in the soil after the end of the experiment.

\begin{tabular}{|c|c|c|c|c|c|c|c|c|c|}
\hline \multirow{3}{*}{$\begin{array}{c}\text { Variant/ } \\
\text { Dose of } N\end{array}$} & \multicolumn{8}{|c|}{$\mathrm{mg} \mathrm{kg}^{-1}$} & \multirow{3}{*}{$\mathrm{K}: \mathrm{Mg}$} \\
\hline & \multicolumn{2}{|c|}{$\mathbf{P}$} & \multicolumn{2}{|c|}{$\mathbf{K}$} & \multicolumn{2}{|c|}{$\mathrm{Ca}$} & \multicolumn{2}{|c|}{$\mathrm{Mg}$} & \\
\hline & Mean & $\pm \mathrm{SE}$ & Mean & $\pm \mathrm{SE}$ & Mean & $\pm \mathrm{SE}$ & Mean & $\pm \mathrm{SE}$ & \\
\hline Soil-default value & $39 d$ & 0.38 & $278 \mathrm{~b}$ & 5.32 & $735 \mathrm{e}$ & 15.60 & $176 b, c$ & 1.46 & 1.58 \\
\hline Control & $122 \mathrm{c}$ & 0.49 & $273 b$ & 3.60 & $904 c$ & 7.05 & $183 a, b, c$ & 0.65 & 0.14 \\
\hline $\begin{array}{c}\text { DG } 80 \\
80 \mathrm{~kg} \mathrm{~N} / \mathrm{ha}\end{array}$ & $120 c$ & 0.65 & $296 b$ & 24.14 & $871 c, e$ & 10.08 & $177 \mathrm{~b}$ & 1.81 & 1.67 \\
\hline $\begin{array}{c}\text { DG } 150 \\
150 \mathrm{~kg} \mathrm{~N} / \mathrm{ha}\end{array}$ & $121 \mathrm{c}$ & 1.82 & $364 b$ & 32.98 & $866 c, e$ & 2.33 & $181 b$ & 1.80 & 2.01 \\
\hline $\begin{array}{c}\text { DG } 220 \\
220 \mathrm{~kg} \mathrm{~N} / \mathrm{ha}\end{array}$ & $124 \mathrm{c}$ & 0.86 & $569^{a}$ & 41.49 & $853 e$ & 8.66 & $184 b$ & 2.93 & 3.09 \\
\hline $\begin{array}{c}\text { NPK } \\
150 \mathrm{~kg} \mathrm{~N} / \mathrm{ha}\end{array}$ & $179 a$ & 2.54 & $365 b$ & 15.80 & $987 \mathrm{~b}$ & 8.76 & $172 \mathrm{c}$ & 3.78 & 2.12 \\
\hline $\begin{array}{c}\text { Compost } \\
150 \mathrm{~kg} \mathrm{~N} / \mathrm{ha}\end{array}$ & $132 b$ & 1.50 & $344 b$ & 19.51 & $1044 a$ & 8.14 & $192 a$ & 1.20 & 1.79 \\
\hline
\end{tabular}

Comment: Average values of plant-available nutrients. Different lower case letters represent HSD (honestly significant difference; post-hoc Tukey's test; $P<0.05$ ) in plant-available nutrient contents. Different lower case letters in black bold font indicate the significantly highest value of plant available nutrients within the respective categories $(\mathrm{P}, \mathrm{K}, \mathrm{Ca}, \mathrm{Mg})$. DG $=\mathrm{digestate}$ NPK = mineral fertilizer containing N, P, K and S in the ratio 10:10:10:13 
In the case of $\mathrm{Mg}$ content in the soil, the variants exhibited the smallest differences. The highest $\mathrm{Mg}$ content was found in variants with the $\mathrm{CP}$ application. The lowest $\mathrm{Mg}$ content was recorded in the variant with the MF application, which was, however, conclusive only in the variants with DG. On the contrary, no significant difference was found between the DG applications. In all variants, except for the MF variant, an increase in Mg content was observed, compared to the pre-experimental soil condition. However, the increase was significant only in the CP variant. Similarly, as in the case of K, the changes in soil $\mathrm{Mg}$ content were linked both to the initial content of nutrients in the fertilizers used, and to the action of individual fertilizers in the soil.

\subsection{Leaching of Mineral Nitrogen}

Total loss of $\mathrm{N}_{\min }$ is shown in Figure 3; losses of the respective forms of $\mathrm{N}_{\min }$, i.e. ammonium and nitrate, is displayed in Appendix B (Figure A3). Figure A3 shows that the largest share was that of the nitrate form. This relates to its negative charge and to the low affinity of soil adsorption complex to the $\mathrm{N}_{\text {min }}$ form [37,38]. The measured values point to the significantly highest loss $(p<0.05)$ of $\mathrm{N}_{\min }$ in the NPK variant, where MF was applied, when compared to the other variants. The Nmin loss in this variant was almost seven times higher than in the control variant (Table 8). Compared to both variants with the DG application, $\mathrm{N}_{\min }$ was higher by $291 \%$ (vs. DG 220) to $670 \%$ (DG 80 ). The measured values confirm that the $\mathrm{CP}$ application (compost variant) affected the elimination (Table 8) of $\mathrm{N}_{\text {min }}$ loss from the topsoil most significantly as it was the lowest among the variants (Figure 3). Apparently, DG (doses 150 and $80 \mathrm{~kg} \mathrm{~N} \mathrm{ha}^{-1}$ ) and $\mathrm{CP}$ applications did not have a negative effect on the $\mathrm{N}_{\min }$ loss in comparison with NPK variants. Nitrogen leaching from organic fertilizers is often substantially lower compared to mineral fertilizers. These nitrates can also contaminate groundwater resources through leaching and adversely affect the physical and chemical properties of water [39,40]. Compared with the conventional $\mathrm{MF}$, the effect of $\mathrm{CP}$ application significantly reduced the loss of $\mathrm{N}_{\min }$.

Table 8. Percentage differences in the leaching of mineral nitrogen.

\begin{tabular}{ccc}
\hline \multirow{2}{*}{ Variant } & Dose of N $\left.\mathbf{~} \mathbf{k g ~ h a} \mathbf{~}^{\mathbf{- 1}}\right)$ & Differences \\
\cline { 3 - 3 } & & Leaching of $\mathbf{N}_{\mathbf{m i n}}$ \\
\hline Control & 0 & $100 \%$ \\
DG 80 & 80 & $103 \%$ \\
DG 150 & 150 & $136 \%$ \\
DG 220 & 220 & $239 \%$ \\
NPK & 150 & $694 \%$ \\
Compost & 150 & $98 \%$ \\
\hline
\end{tabular}

Comment: Percentage differences between the control and other variants. DG $=$ digestate, $\mathrm{NPK}=$ mineral fertilizer containing $\mathrm{N}, \mathrm{P}, \mathrm{K}$ and $\mathrm{S}$ in the ratio 10:10:10:13.

Differences in leaching of $\mathrm{N}_{\min }$ between the variants with the application of $\mathrm{CP}$ and DG can be explained by their different composition. The ratio of organic and mineral $\mathrm{N}$ content is 50:50 in DG. However, this ratio is significantly different for compost, in which the presence of stable organic forms of nitrogen predominates ( $>50 \%$ ). The mineral forms of $\mathrm{N}$ (see the structure of leaching: Appendix B, Figure A3) are more prone to leaching and therefore the above differences were found $[41,42]$. The positive effect of $\mathrm{CP}$ application to increase usability of $\mathrm{N}$ substances in the soil and thus to reduce $\mathrm{N}_{\min }$ loss from the soil has already been investigated and compared with conventional technologies [43-45]. With respect to the results of agricultural research, the $\mathrm{CP}$ application can be recommended. It can also be applied in sites prone to $\mathrm{N}$ substance leaching, e.g. to watercourses or groundwater resources $[9,38]$ because $\mathrm{CP}$ composition is specific (humic substances, polysaccharides, etc.) as it contains a considerable amount of stable organic substances [11]. These substances support both parts of the adsorption complex: organic and mineral (or inorganic), which are necessary for the retention of $\mathrm{N}$ and other substances [46]. 
The $\mathrm{N}_{\min }$ loss can be compared with respect to the different DG doses (Table 1), i.e., from $220 \mathrm{~kg}$ $\mathrm{N} \mathrm{ha}^{-1}$ (70,968 $\mathrm{kg}$ DG per hectare) to $80 \mathrm{~kg} \mathrm{~N} \mathrm{ha}^{-1}$ (25,806 $\mathrm{kg}$ DG per hectare). It is evident that with the lower fertilizer dose, and hence the lower $\mathrm{N}$, its loss is reduced, which is not surprising, and it is in accordance with the conclusions of other scientific studies $[9,18,38,44]$. However, a comparison of the values with plant biomass production is much more significant (Table 9). In the DG variant (150 kg N $\mathrm{ha}^{-1}$ ), plant biomass production (above-, underground, and total) was the highest-Table 9) compared to the control variant, the DG 220 and the CP variants. However, the second-lowest loss of $\mathrm{N}_{\min }$ was found there (DG 150 variant). It can be concluded that the DG dose in the variant was optimal to reach high biomass production at the lowest possible $\mathrm{N}_{\min }$ loss from the soil. On the other hand, this result was obtained from the pot experiment. In follow-up research, our findings should be verified in a field experiment with other indicating crops.

DG has a different ratio of $C$ and $N$ substances than CP. The C:N ratio in DG is usually $<10: 1$, while a large part of $\mathrm{N}$ substances is in mineral form [47], and it has different effects on soil fertility and $\mathrm{N}$ substance usability in soil $[48,49]$. DG digestate as well as pig slurry belong to fast-release $\mathrm{N}$ fertilizers $(\mathrm{C}: \mathrm{N}<10)$, which can both have a positive effect on plant nutrition and can be potentially negative for $\mathrm{N}$ loss from the soil. DG contains sufficient amounts of $\mathrm{N}$-compounds, which may cover the $\mathrm{N}$ requirements of plants (DG partly acted as mineral fertilizer) and soil microbes. On the other hand, it does not contain enough C-compounds (Table 2-Chemical characteristics of DG and CP). Therefore, soil microbes do not have energy enough for metabolic processes of $\mathrm{N}$ compounds [32,41,50,51]. $\mathrm{CP}$ showed a lower $\mathrm{N}_{\min }$ loss at the same $\mathrm{N}$ dose (variants DG 150 and compost) because $\mathrm{N}$ was applied in stable organic form and its mineralization was slower as the C:N ratio was > 10:1 [38,47,50].

The comparison of $\mathrm{N}_{\min }$ loss and biomass production from the mentioned DG 150 variant with the MF variant shows lower results in the DG variant. Despite the highest $\mathrm{N}_{\min }$ loss, a similar production of biomass was found in the variant (NPK), as in all variants with DG application. This indicates that an excessive amount of N was applied to the NPK variant, because the plant was able to produce aboveground and underground biomass, even at its significant loss. The relationship between $\mathrm{N}_{\text {min }}$ loss and biomass production can be characterized by using principal component analysis (PCA) and regression analysis. The results are displayed in Appendix B (Figure A4). Two important factors (PC 1 and 2) were identified based on PCA. PC 1 describes $>51 \%$ of the variance and PC $2>35 \%$ of the additional variance. The first factor (PC 1) had a strong positive correlation with the loss of $\mathrm{N}_{\min }$ from the soil $(R=0.89)$ and with the P content in the soil after the experiment $(R=0.84)$. Conversely, this factor correlated negatively with soil microbial activity (expressed using the BAS parameter; $R=-0.81$ ). Therefore, it can be concluded that this factor is likely to characterize the amount and form (organic or mineral) of $\mathrm{N}$ applied. Increasing inputs, especially of mineral $\mathrm{N}$ forms, led to increased $\mathrm{N}_{\text {min }}$ loss. The excessive $\mathrm{N}$ was not used to produce biomass. Conversely, PC 2 showed a minimal correlation to the $\mathrm{N}_{\min }$ loss $(R=0.12)$, a strong positive correlation to the biomass production $(R=0.94)$ and a slightly positive correlation to BAS $(R=0.41)$. This factor is probably related to fertilizer type and substances contained therein (organic compounds, minerals etc.).

\subsection{Plant Biomas Production of Lactuca sativa L.}

Production of plant biomass was divided into aboveground and underground parts and was completed with the root/shoot ratio (Table 9; R:S). The reason is that on assessing the yield effect of the applied soil supplement, the aboveground was found to be mainly affected. On the contrary, the influence on the root system is of particular importance in terms of the action of individual substances on the development of the plant. Thus, the respective experimental variants could be assessed from several viewpoints.

If we compare the variants with the same amount of N (150 kg) applied (DG, NPK, CP), it can be concluded that both DG and MF have the same effect on the total production of plant biomass. The DG variant, particularly, was able to generate more aboveground biomass. However, the difference was statistically insignificant. In the case of underground biomass, the highest production of biomass 
was found in DG $150 \mathrm{~kg} \mathrm{~N}$ ha $^{-1}$. Moreover, the highest level of R:S ratio was also found. The results and values of $\mathrm{N}_{\min }$ leaching point to the fact that the DG $150 \mathrm{~kg} \mathrm{~N}$ ha $^{-1}$ dose was optimal in $\mathrm{N}$ plant nutrition, when compared to DG $220 \mathrm{~kg} \mathrm{~N}$ ha or NPK $150 \mathrm{~kg} \mathrm{~N} \mathrm{ha}^{-1}$. This is because the development of the aboveground and underground biomass was observed (the highest $R / S ; 0.33$ ) at low $N_{\min }$ loss (only $36 \%$ higher than in the non-fertilized control variant).

Table 9. Average yields of plant biomass (Lactuca sativa L.-lettuce).

\begin{tabular}{|c|c|c|c|c|c|c|c|}
\hline \multirow{3}{*}{ Variant } & \multicolumn{6}{|c|}{ Yields of Plant Biomass $\left(\mathrm{g} 0.01 \mathrm{~m}^{-2}\right)$} & \multirow{3}{*}{$\mathrm{R}: \mathrm{S}$} \\
\hline & \multicolumn{2}{|c|}{ Aboveground } & \multicolumn{2}{|c|}{ Underground } & \multicolumn{2}{|c|}{ Total } & \\
\hline & Mean & $\pm \mathrm{SD}$ & mean & $\pm \mathrm{SD}$ & mean & $\pm \mathrm{SD}$ & \\
\hline Control & $1.89^{\mathrm{b}}$ & 0.19 & $0.29^{b}$ & 0.01 & $2.18^{b}$ & 0.20 & 0.15 \\
\hline DG 80 & $3.28^{a, b}$ & 0.39 & $0.74^{\mathrm{b}}$ & 0.09 & $4.02^{\mathrm{a}}$ & 0.47 & 0.22 \\
\hline DG 150 & $3.57^{\mathrm{a}}$ & 0.23 & $1.19^{\mathrm{a}}$ & 0.11 & $4.76^{\mathrm{a}}$ & 0.34 & 0.33 \\
\hline DG 220 & $2.90^{\mathrm{b}}$ & 0.47 & $0.65^{b}$ & 0.05 & $3.55^{\mathrm{a}, \mathrm{b}}$ & 0.48 & 0.22 \\
\hline NPK & $3.04^{\mathrm{a}, \mathrm{b}}$ & 0.43 & $0.75^{b}$ & 0.02 & $3.79^{\mathrm{a}}$ & 0.42 & 0.24 \\
\hline Compost & $1.79^{\mathrm{b}}$ & 0.19 & $0.21^{b}$ & 0.03 & $2.00^{\mathrm{b}}$ & 0.22 & 0.11 \\
\hline
\end{tabular}

Comment: Average values of plant biomass production detected in the experimental container. Different lower case letters represent HSD (honestly significant difference; post-hoc Tukey's test; $p<0.05$ ) in biomass production. DG = digestate, NPK = mineral fertilizer containing N, P, K and S in the ratio 10:10:10:13; R:S refers to Root to Shoot ratio.

The above results demonstrate the $\mathrm{N}$ nutrition effect on plant biomass production, its development [52], and subsequent $\mathrm{N}_{\min }$ loss from the soil [18]. On the other hand, $\mathrm{CP}$ application with the same amount of $\mathrm{N}$ had a significantly worse effect on both, the total and aboveground production of plant biomass. This was due to a lower C:N ratio in the variant with DG; therefore, the applied nutrients were readily available, compared to the variant where $\mathrm{CP}$ was applied. $\mathrm{CP}$ has to be mineralized to release nutrients. The results are consistent with $[11,53]$, who also confirm that in the short term, CP can have a small effect in promoting plant biomass production. On the other hand, in the long run, $\mathrm{CP}$ increases the content of soil nutrients and creates conditions for long-term fertility, which is well documented by data on plant-available nutrient content (Table 7). As for long-term application, $\mathrm{CP}$ has a positive effect on the availability of $\mathrm{N}$ to crops and $\mathrm{N}$-use efficiency was comparable to the mineral $\mathrm{N}$ fertilizer [54]. The reason for this is, according to $[11,54,55]$, that the chemical composition of $\mathrm{CP}$ containing $\mathrm{C}$ - and $\mathrm{N}$ - substances tied in organic bonds have to be subjected to a mineralization process for release. In addition, a considerable part of $\mathrm{N}$ from $\mathrm{CP}$ could have been apparently incorporated into the complex of SOM because the $\mathrm{CP}$ fertilized variant exhibited the lowest biomass production (Table 9), but at the same time minimal $\mathrm{N}$ losses from the soil (Figure 3). Furthermore, it is necessary to note that a standard dose is $>30,000 \mathrm{~kg} \mathrm{ha}^{-1}$ (WRAP 2000). According to EN 465735 , the recommended dose is $50,000 \mathrm{~kg} \mathrm{ha}^{-1}$ once per five years. In our experiment, the applied dose was $<10,000 \mathrm{~kg} \mathrm{ha}^{-1}$, probably too low for sufficient biomass production. Compost (generally organic amendment with a wide $\mathrm{C}: \mathrm{N}$ ratio, not $\mathrm{DG}$ ) represents fertilizers suitable for crops with a longer growing season (need for slow $\mathrm{N}$ release), and this is why the yield effect logically did not show in lettuce [11,56].

Diaz et al. [11] and Baldi et al. [36] report that this process creates a condition for the gradual release of nutrients from the applied CP. Thus, they can be used by plants or stored in microorganisms. It supports the above-stated long-term soil fertility and also promotes increase in soil capacity for nutrients, i.e. development of soil absorption complex [57].

In the case of increased $\left(220 \mathrm{~kg} \mathrm{~N} \mathrm{ha}^{-1}\right)$ and reduced dose of $\mathrm{N}\left(80 \mathrm{~kg} \mathrm{~N} \mathrm{ha}^{-1}\right)$ in DG, it can be stated that the increased dose was likely to have a phytotoxic effect on the plants, compared to the other doses of DG, as the production of both aboveground and underground biomass was lower. On the other hand, it is important to note that the data were conclusive only in the resulting underground biomass. In the overall assessment of the measured data, it is clear that the DG application, as $\mathrm{N}$ nutrition, may compete with the conventional mineral fertilizer (NPK), which is due to the low C: N ratio and high $\mathrm{N}$ content [47]. However, it is important to choose an optimal dose in order to apply $\mathrm{N}$ 
to be utilizable by plants. Nevertheless, $\mathrm{CP}$ cannot itself become a separate source of $\mathrm{N}$ substance for the plant. It is a way to increase long-term soil fertility (a positive effect on the nutrient content in soil and on $\mathrm{N}_{\min }$ leaching from the soil). The data confirm the biomass production in the $\mathrm{CP}$ variant to have been at the same level as in the control variant and always significantly lower than in the DG or MF application variants.

\section{Conclusions}

This study deals with the assessment of the effect of the application of commonly available soil supplements on select indicators in a soil environment. The effect of digestate, compost, and mineral fertilizer was monitored in a laboratory experiment. Individual doses of fertilizers were determined on the basis of nitrogen content. The measured values confirm that each fertilizer acted differently in the selected parameters. In general, it can be stated that fertilizers with a higher content of organic substances had a positive effect on soil microbial activities and thus probably on soil mineral-organic complex. Consequently, it played an important role in eliminating mineral nitrogen leaching from arable land, as all digestate or compost fertilized variants showed a demonstrably lower mineral nitrogen loss, compared to the mineral fertilizer variant. When comparing compost and digestate, the different characters of both fertilizers is evident, especially in terms of the C:N ratio. Digestate positively influenced microbial activity in the soil and production of plant biomass. At reduced doses (150 and $80 \mathrm{~kg} \mathrm{~N} \mathrm{ha}^{-1}$ ), it had a positive effect on the reduction of mineral nitrogen leaching from the soil (compared to the control variant). On the other hand, the long-term effect of digestate application remains questionable. In field conditions, the effect of digestate on the leaching of mineral $\mathrm{N}$ from soil can be influenced not only by its composition but also by soil conditions, climatic conditions, and crop species. Conversely, the application of compost $\left(150 \mathrm{~kg} \mathrm{~N} \mathrm{ha}^{-1}\right)$ had a positive effect on increase in the content of basic nutrients in the soil, especially $\mathrm{Ca}$ and $\mathrm{Mg}$ (demonstrable against other variants) and on elimination of mineral nitrogen loss from the soil (by $7 \%$ lower than in the control variant). Based on the measured values, it can be concluded that the digestate at $150 \mathrm{~kg} \mathrm{~N} \mathrm{ha}^{-1}$ dose may present a potential alternative to increasing current soil fertility and thus partially replacing conventional mineral nutrition. If, within a particular crop rotation, farmers are able to supplement the long-term digestate application with the application of compost, they will contribute to maintaining and strengthening long-term soil fertility.

Author Contributions: J.E. and J.Š. organized the laboratory experiment; M.D.V. and P.Š. reviewed the manuscript; J.E. and A.K. performed the statistical analyses; M.D.V. and M.B. approved the manuscript for submission. All authors have read and agreed to the published version of the manuscript.

Funding: The research was funded by the Ministry of Agriculture of the Czech Republic, institutional support MZE-RO1720. Furthermore, the work was supported by a project at the Technology Agency of the Czech Republic TH04030132: "Application Systems of Liquid Organic Fertilizers as the Means to Improve Soil Environment, Enhance Nutrient Utilization by Plants and Minimize Environmental Impacts".

Conflicts of Interest: The authors declare no conflicts of interest. 


\section{Appendix A}

\section{Design of the Experiment}

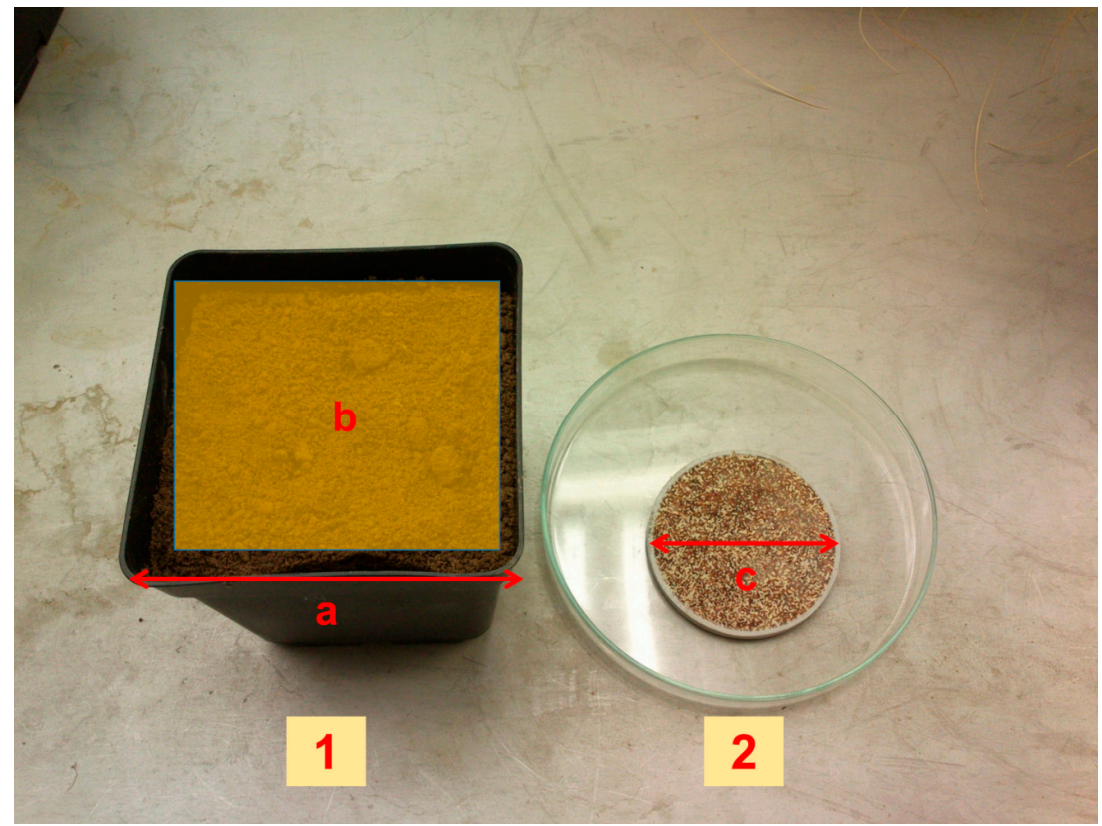

Figure A1. Experimental pot, view from above-1: plastic container $\left(\mathrm{a}=10 \mathrm{~cm} ; \mathrm{b}=100 \mathrm{~cm}^{2}\right) ; 2$ : Petri dish with IER disc $(\mathrm{c}=7.5 \mathrm{~cm})$.

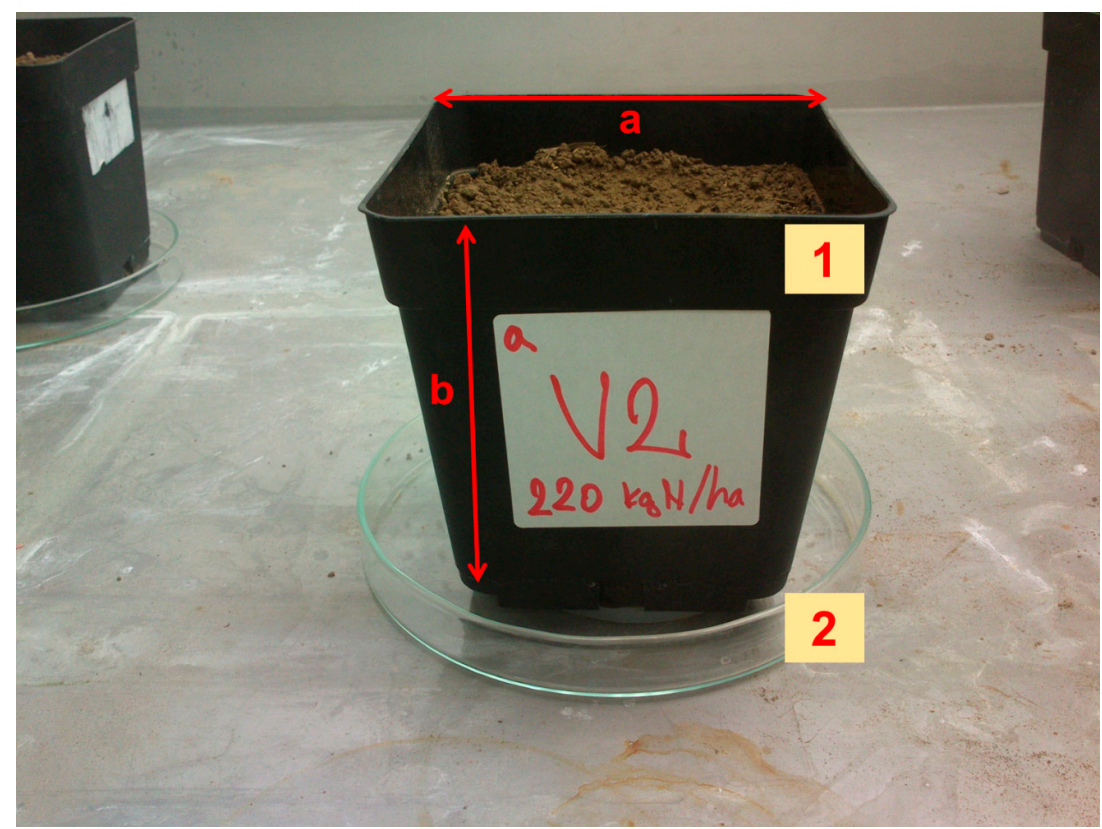

Figure A2. Experimental pot, side view-1: plastic container $(a=10 \mathrm{~cm} ; b=11 \mathrm{~cm})$; 2: Petri dish with IER disc. 


\section{Appendix B}

\section{Additional Statistically Processed Data}

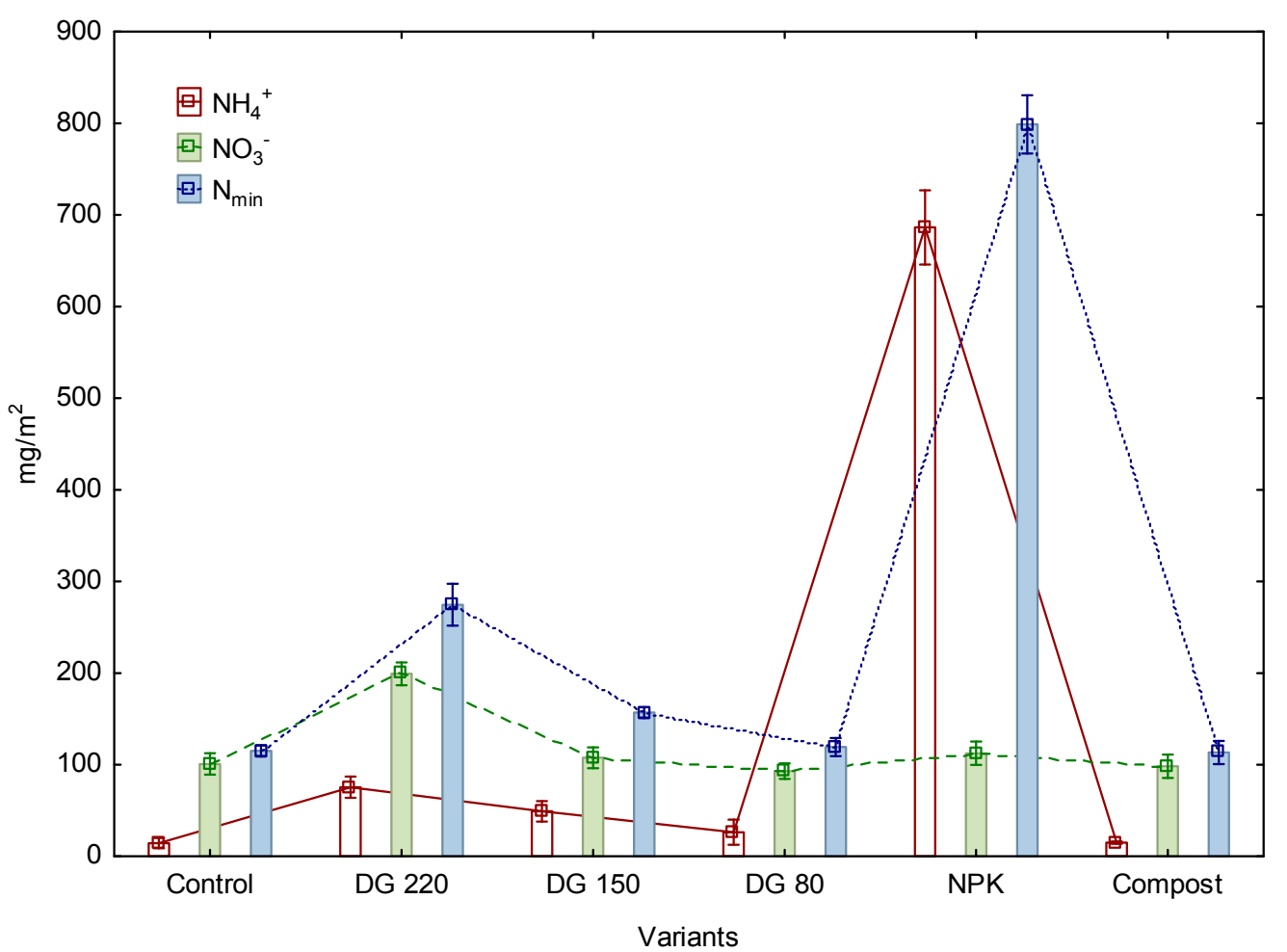

Figure A3. Overview of $\mathrm{N}_{\text {min }}$ leaching in the experiment. $\mathrm{N}_{\min }$ loss is displayed by ammonia-N and nitrate- $\mathrm{N}$ forms in the respective variants.

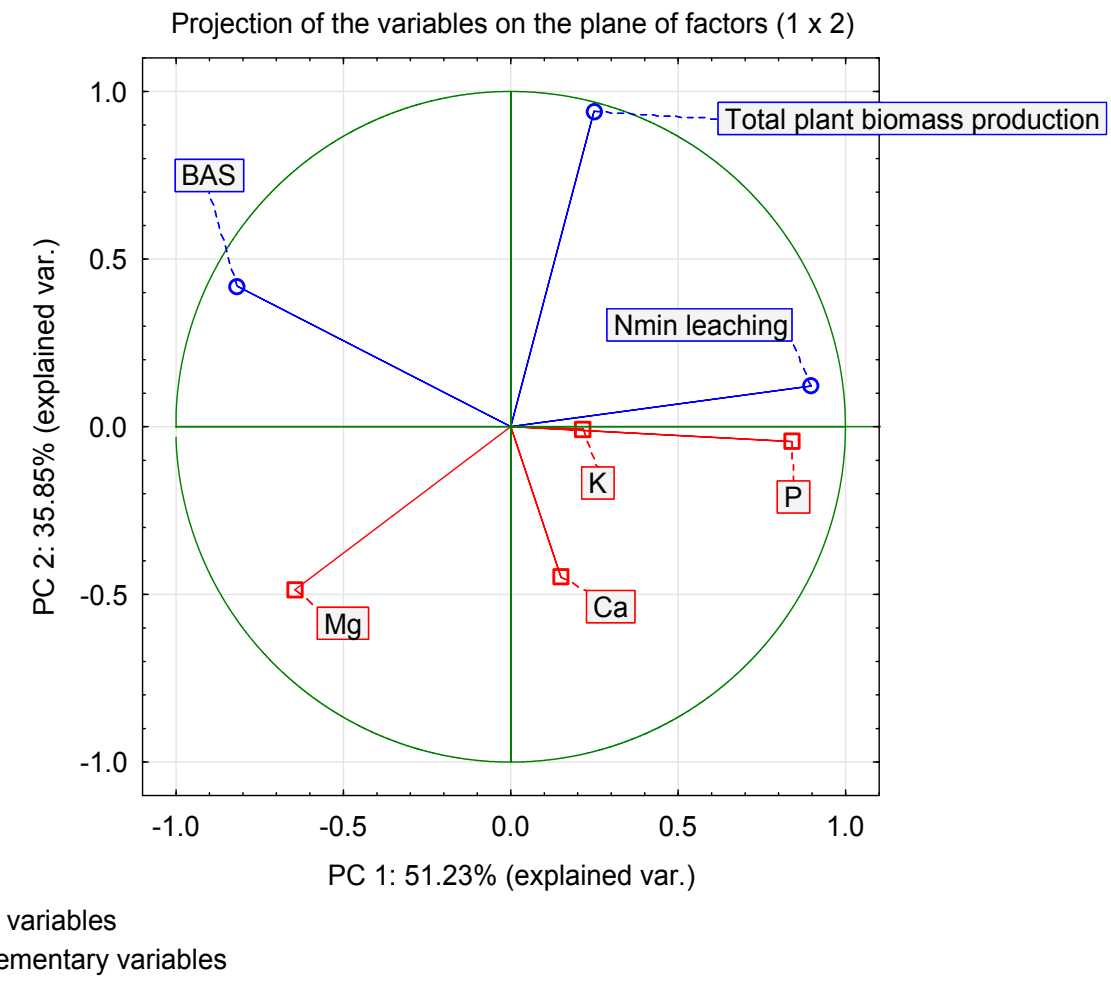

Figure A4. Principal Component Analysis (PCA)—visualization of correlations between selected parameters and factors. 


\section{References}

1. Altieri, M.A.; Nicholls, C.I. Agroecology and the Search for a Truly Sustainable Agriculture, 1st ed.; United Nations Environment Programme: Mexico City, Mexico, 2005; p. 291.

2. Möller, K. Effects of anaerobic digestion on soil carbon and nitrogen turnover, $\mathrm{N}$ emissions, and soil biological activity. A review. Agron. Sustain. Dev. 2015, 35, 1021-1041. [CrossRef]

3. Smith, P.; Martino, D.; Cai, Z.; Gwary, D.; Jensen, H.; Kumar, P.; McCarl, B.; Ogle, S.; O’Mara, F.; Rice, C.; et al. Policy and technological constraints to implementation of greenhouse gas mitigation options in agriculture. Agric. Ecosyst. Environ. 2007, 118, 6-28. [CrossRef]

4. Sadet-Bourgeteau, S.; Hout, S.; Karimi, B.; Mathieu, O.; Mercier, V.; Montenach, D.; Morvan, T.; Sappin-Didier, V.; Watteau, V.; Nowak, V.; et al. Microbial communities from different soil types respond differently to organic waste input. Appl. Soil Ecol. 2019, 143, 70-79. [CrossRef]

5. Scaglia, B.; Pognani, M.; Adani, F. Evaluation of hormone-like activity of the dissolved organic matter fraction (DOM) of compost and digestate. Sci. Total Environ. 2015, 514, 314-321. [CrossRef]

6. Harrison-Kirk, T.; Beare, M.H.; Meenken, E.D.; Condron, L.M. Soil organic matter and texture affect responses to dry/wet cycles: Changes in soil organic matter fractions and relationships with $\mathrm{C}$ and $\mathrm{N}$ mineralisation. Soil Biol. Biochem. 2014, 74, 50-60. [CrossRef]

7. Wolf, B.; Snyder, G.H. Sustainable Soils: The Place of Organic Matter in Sustaining Soils and Their Productivity, 1st ed.; CRC Press: Binghamton, NY, USA, 2003; p. 380.

8. Schimel, J.P.; Bennett, J. Nitrogen mineralization: Challenges of a changing paradigm. Ecology 2004, 85, 591-602. [CrossRef]

9. Sutton, M.A.; Howard, C.; Erisman, J.; Billen, G.; Bleeker, A.; Grennfelt, P.; van Grinsven, H.; Grizzetti, B. Assessing our nitrogen inheritance and the challenge to integrate nitrogen science and policies: The European Nitrogen Assessment approach. In The European Nitrogen Assessment: Sources, Effects and Policy Perspectives, 1st ed.; Binghamton Sutton, M.A., Howard, C., Erisman, J., Billen, G., Bleeker, A., Grennfelt, P., van Grinsven, H., Grizzetti, B., Eds.; Cambridge University Press: New York, NY, USA, 2011; pp. 1-6 and pp. 82-96.

10. Caracciolo, A.B.; Bustamante, M.A.; Nogues, I.; Di Lenola, M.; Luprano, M.L.; Grenni, P. Changes in microbial community structure and functioning of a semiarid soil due to the use of anaerobic digestate derived composts and rosemary plants. Geoderma 2015, 245-246, 89-97. [CrossRef]

11. Diaz, L.F.; De Bertoldi, M.; Bidlingmaier, W. Compost Science and Technology, 1st ed.; Elsevier Science: Boston, MA, USA, 2007; p. 364.

12. Francioli, D.; Schulz, E.; Lentendu, G.; Wubet, T.; Buscot, F.; Reitz, T. Mineral vs. organic amendments: Microbial community structure, activity and abundance of agriculturally relevant microbes are driven by long-term fertilization strategies. Front Microbiol. 2016, 14, 1446. [CrossRef]

13. Farina, R.; Testani, E.; Campanelli, G.; Leteo, F.; Napoli, R.; Canali, S.; Tittarelli, F. Potential carbon sequestration in a Mediterranean organic vegetable cropping system. A model approach for evaluating the effects of compost and Agro-ecological Service Crops (ASCs). Agric. Syst. 2018, 162, 239-248. [CrossRef]

14. Chalhoub, M.; Garnier, P.; Coquet, Y.; Mary, B.; Lafolie, F.; Houot, S. Increased nitrogen availability in soil after repeated compost applications: Use of the PASTIS model to separate short and long-term effects. Soil Biol. Biochem. 2013, 65, 144-157. [CrossRef]

15. Claassen, V.P.; Carey, J.L. Comparison of slow-release nitrogen yield from organic soil amendments and chemical fertilizers and implications for regeneration of disturbed sites. Land Degrad. Dev. 2007, 132, 119-132. [CrossRef]

16. Tiwary, A.; Williams, I.D.; Pant, D.C.; Kishore, V.V.N. Assessment and mitigation of the environmental burdens to air from land applied food-based digestate. Environ. Pollution. 2015, 203, 262-270. [CrossRef] [PubMed]

17. Massaccesi, L.; Sordi, A.; Micale, C.; Cucina, M.; Zadra, C.; Di Maria, F.; Gigliotti, G. Chemical characterization of percolate and digestate during the hybrid solid anaerobic digestion batch process. Process Biochem. 2013, 48, 1361-1367. [CrossRef]

18. Wang, J.; Snah, D.; Zhang, G.; Wang, Y.; Wang, C.; Teng, Y.; Christie, P. Nitrogen and phosphorus leaching losses from intensively manager paddy fields with straw retention. Agric. Water Manag. 2014, 141, 66-73. [CrossRef] 
19. Valkama, E.; Salo, T.; Esala, M.; Turtola, E. Nitrogen balances and yields of spring cereals as affected by nitrogen fertilization in northern conditions: A meta-analysis. Agric. Ecosyst. Environ. 2013, 164, 1-13. [CrossRef]

20. D'antuono, L.F.; Neri, R. The evaluation of nitrogen effect on lettuce quality by means of descriptive sensory profiling. Acta Hortic. 2001, 563, 217-223. [CrossRef]

21. Šimek, M.; Virtanen, S.; Krištůfek, V.; Simojoki, A.; Yli-Halla, M. Evidence of rich microbial communities in the subsoil of boreal acid sulphate soil conductive to greenhouse gas emissions. Agric. Ecosyst. Environ. 2011, 140, 113-122. [CrossRef]

22. Mehlich, A. Mehlich 3 soil test extractant: A modification of Mehlich 2 extractant. Commun. Soil Sci. Plant Anal. 1984, 15, 1409-1416. [CrossRef]

23. Zbíral, J. Analysis of Soils I. Unified Techniques, 2nd ed.; Central Institute for Supervising and Testing in Agriculture: Brno, Czech Republic, 2002. (In Czech)

24. Maňásek, J.; Lošák, T.; Prokeš, K.; Hlušek, J.; Vítězová, M.; Škarpa, P.; Filipčík, R. Effect of nitrogen and Potassium fertilization on micronutrient content in grain maize (Zea mays L.). Acta Univ. Agric. Silvic. Mendel. Brun. 2013, 61, 123-128. [CrossRef]

25. Uzoma, K.C.; Inoue, M.; Andry, H.; Fujimaki, H.; Zahoor, A.; Nishihara, E. Effect of cow manure biochar on maize productivity under sandy soil condition. Soil Use Manag. 2011, 27, 205-212. [CrossRef]

26. Novosadová, I.; Záhora, J.; Ruiz-Sinoga, J.D. The availability of mineral nitrogen in Mediterranean open steppe dominated by Stipa tenacissima L. Acta Univ. Agric. Silvic. Mendel. Brun. 2011, 59, 187-192. [CrossRef]

27. Muñoz-Huerta, R.F.; Guevara-Gonzalez, R.G.; Contreras-Medina, L.M.; Torres-Pacheco, I.; Prado-Olivarez, J.; Ocampo-Velazquez, R.V. Review of methods for sensing the nitrogen status in plants: Advantages, disadvantages and recent advances. Sensors 2013, 13, 10823-10843. [CrossRef] [PubMed]

28. Ananyeva, N.D.; Susyan, E.A.; Chernova, O.V.; Wirth, S. Microbial respiration activities of soils from different climatic regions of European Russia. Eur. J. Soil Biol. 2008, 44, 147-157. [CrossRef]

29. Bloem, J.; Hopkins, D.W.; Benedetti, A. Microbiological Methods for Assessing Soil Quality, 1st ed.; CABI: Wallingford, UK, 2006; p. 320.

30. Geisseler, D.; Horwath, W.R.; Doane, T.A. Significance of organic nitrogen uptake from plant residues by soil microorganisms as affected by carbon and nitrogen availability. Soil Biol. Biochem. 2009, 41, 1281-1288. [CrossRef]

31. Yang, X.; Chen, X.; Yang, X. Effect of organic matter on phosphorus adsorption and desorption in a black soil from Northeast China. Soil Tillage 2019, 187, 85-91. [CrossRef]

32. Peng, S.Z.; Yang, S.H.; Xu, J.Z.; Luo, Y.F.; Hou, H.J. Nitrogen and phosphorus leaching losses from paddy fields with different water and nitrogen managements. Paddy Water Environ. 2011, 9, 333-342. [CrossRef]

33. Courtney, R.G.; Mullen, G.J. Soil quality and barley growth as influenced by the land application of two compost types. Biores. Technol. 2007, 99, 2913-2918. [CrossRef]

34. Gil, M.V.; Carballo, M.T.; Calvo, L.F. Fertilization of maize with compost from cattle manure supple-mented with additional mineral nutrients. Waste Manag. 2007, 28, 1432-1440. [CrossRef]

35. Radziemska, M.; Vaverková, M.D.; Adamcová, D.; Brtnický, M.; Mazur, Z. Valorization of fish waste compost as a fertilizer for agricultural use. Waste Biomass Valori. 2016, 10, 2537-2545. [CrossRef]

36. Baldi, E.; Toselli, M.; Marcolini, G.; Quartieri, M.; Cirillo, E.; Innocenti, A.; Marangoni, B. Compost can successfully replace mineral fertilizers in the nutrient management of commercial peach orchard. Soil Use Manag. 2010, 26, 346-353. [CrossRef]

37. Hachiya, T.; Sakakibara, H. Interactions between nitrate and ammonium in their uptake, allocation, assimilation, and signaling in plants. J. Exp. Bot. 2017, 68, 2501-2512. [CrossRef] [PubMed]

38. Zheng, C.H.; Zhang, Z.; Wu, Y.; Mwiya, R. Response of vertical migration and leaching of nitrogen in percolation water of paddy fields under water-saving irrigation and straw return conditions. Water 2019, 11, 868. [CrossRef]

39. Obire, O.; Ogan, A.; Okigbo, R.N. Impact of fertilizer plant effluent on water quality. Int. J. Environ. Sci. Technol. 2008, 5, 107-118. [CrossRef]

40. Namdev, G.R.; Bajpai, A.; Malik, S. Effect of chemical fertilizers on water quality of irrigation reservoir (Kaliasote Reservoir) of Bhopal (M.P.). Curr. World. Environ. 2011, 6, 169-172. [CrossRef]

41. Makádi, M.; Tomócsik, A.; Orosz, V. Digestate: A new nutrient source-Review. In Biogas, 1st ed.; Kumar, S., Ed.; IntechOpen: Rijeka, Croatia, 2012; pp. 295-310. 
42. Lošák, T.; Hlušek, J.; Válka, T.; Elbl, J.; Vítěz, T.; Bělíková, H.; Von Bennewitz, E. The effect of fertilisation with digestate on kohlrabi yields and quality. Plant Soil Environ. 2016, 62, 274-278. [CrossRef]

43. Bazzoffi, P.; Pellegrini, S.; Rocchini, A.; Morandi, M.; Grasselli, O. The effect of urban refuse compost and different tractors tyres on soil physical properties, soil erosion and maize yield. Soil Tillage Res. 1998, 48, 275-286. [CrossRef]

44. Nevens, F.; Reheul, D. The application of vegetable, fruit and garden waste compost in addition to cattle slurry in a silage maize monoculture: Nitrogen availability and use. Eur. J. Agron. 2003, 19, 189-203. [CrossRef]

45. Huang, T.; Ju, X.; Yang, H. Nitrate leaching in a winter wheat-summer maize rotation on a calcareous soil as affected by nitrogen and straw management. Sci. Rep. 2017, 7, 42247. [CrossRef]

46. Shaheen, S.M.; Tsadilas, C.D.; Rinklebe, J. A review of the distribution coefficients of trace elements in soils: Influence of sorption system, element characteristics, and soil colloidal properties. Adv. Colloid Interface Sci. 2013, 201-202, 43-56. [CrossRef]

47. Wang, Y.; Chikamatsu, S.; Gegen, T.; Sawada, K.; Toyota, K.; Riya, S.; Hosomi, M. Application of biogas digestate with rice straw mitigates nitrate leaching potential and suppresses root-knot nematode (Meloidogyne incognita). Agronomy 2019, 9, 227. [CrossRef]

48. Tambone, F. Adani, Nitrogen mineralization from digestate in comparison to sewage sludge, compost and urea in a laboratory incubated soil experiment. J. Plant Nutr. Soil Sci. 2017, 180, 355-365. [CrossRef]

49. Möller, K.; Müller, T. Effects of anaerobic digestion on digestate nutrient availability and crop growth: A review. Eng. Life Sci. 2012, 12, 242-257.

50. Schievano, A.; Adani, F.; Tambone, F.; D’imporzano, G.; Scaglia, B.; Genevini, P.L. What Is the Digestate? 1st ed.; Faculty of Agricultural Sciences, University of Milano: Milano, Italy, 2009.

51. Johansen, A.; Carter, M.S.; Jensen, E.S.; Hauggard-Nielsen, H.; Ambus, P. Effects of digestate from anaerobically digested cattle slurry and plant materials on soil microbial community and emission of $\mathrm{CO}_{2}$ and $\mathrm{N}_{2} \mathrm{O}$. Appl. Soil Ecol. 2013, 63, 36-44. [CrossRef]

52. Lošák, T.; Hlušek, J.; Filipčík, R.; Pospíšilová, L.; Maňásek, J.; Prokeš, K.; Buňka, F.; Kráčmar, S.; Martensson, A.; Orosz, F. Effect of nitrogen fertilization on metabolisms of essential and non-essential amino acids in field-grown grain maize (Zea mays L.). Plant Soil Environ. 2010, 56, 574-579. [CrossRef]

53. Al-Bataina, B.; Young, T.M.; Ranieri, E. Effects of compost age on the release of nutrients. ISWCR 2016, 4, 230-236. [CrossRef]

54. Gutser, R.; Ebertseder, T.; Weber, A.; Schraml, M.; Schmidhalter, U. Short-term and residual availability of nitrogen after long-term application of organic fertilizers on arable land. J. Plant Nutr. Soil Sci. 2005, 168, 439-446. [CrossRef]

55. Sánchez-Monedero, M.A.; Cayuela, M.L.; Sánhez-Garcia, M.; Vandecasteele, B.; D’Hose, T.; López, G.; Martínez-Gaitán, C.; Kuikman, P.J.; Sinicco, T.; Mondini, C. Agronomic evaluation of biochar, compost and biochar-blended compost across different cropping systems: Perspective from the European project FERTIPLUS. Agronomy 2019, 9, 225. [CrossRef]

56. Martínez-Blanco, J.; Lazcano, C.; Christensen, T.H.; Muñoz, P.; Rieradevall, J.; Møller, J.; Antón, A.; Boldrin, A. Compost benefits for agriculture evaluated by life cycleassessment. A review. Agron. Sustain. Dev. 2013, 33, 721-732. [CrossRef]

57. Hernández, T.; Chocano, C.; Moreno, J.L.; García, C. Use of compost as an alternative to conventional inorganic fertilizers in intensive lettuce (Lactuca sativa L.) crops-Effects on soil and plant. Soil Till. Res. 2016, 160, 14-22. [CrossRef]

(C) 2020 by the authors. Licensee MDPI, Basel, Switzerland. This article is an open access article distributed under the terms and conditions of the Creative Commons Attribution (CC BY) license (http://creativecommons.org/licenses/by/4.0/). 